\title{
Development of acquisition and 24-h retention of a directional one-way active avoidance response in infant Swiss mice
}

\author{
Z. MICHAEL NAGY, JAMES CHIEN-SHIH KU, and KENNETH J. PORADA \\ Bowling Green State University, Bowling Green, Ohio 43403
}

\begin{abstract}
In order to determine the age at which Swiss-Webster mice first became capable of learning and exhibiting 24-h retention of a directional, one-way active avoidance response, six separate groups of 20 mice received 25 active avoidance training trials at selected ages between 11 and 21 days of age. Equal numbers of yoked-shock control mice received identical amounts of shock and handling as their trained littermates on each trial. Following a 24 -h retention interval, all groups received 25 active avoidance training trials. The acquisition results indicated that, while all age groups were capable of emitting some successful avoidances, within-session improvement was not apparent until 17 days of age. Comparisons of retest scores by trained mice with their formerly yoked-shocked littermates revealed that reliably more avoidances were made by mice with prior training beginning at 17 days of age. In general, the results suggest that the ability to acquire and remember for $24 \mathrm{~h}$ an active avoidance response emerges around 15-17 days of age for Swiss mice on this directional task.
\end{abstract}

Recent reviews of the rapidly growing literature concerned with age-related differences in learning and memory have suggested that, whereas long-term memory abilities for a variety of learning tasks markedly improve from infancy to adulthood in altricial animals, agerelated differences in learning abilities appear task specific (Campbell \& Coulter, 1976; Nagy, 1979). For tasks requiring the withholding of a response, such as passive avoidance, young rats have consistently been reported to acquire the response at a slower rate than adults (e.g., Feigley \& Spear, 1970; Riccio, Rohrbaugh, \& Hodges, 1968; Riccio \& Schulenburg, 1969). In contrast, tasks that require a response to be made appear to be learned equally well by both the young and adults (e.g., Campbell, Misanin, White, \& Lytle, 1974; Crockett \& Nobel, 1963; Smith, 1968). These kinds of findings led Campbell and Coulter (1976) to tentatively conclude that a certain level of maturity is not a necessary condition for animals to acquire the basic response-reinforcement contingencies that characterize simple approach and escape tasks. When performance deficiencies have been reported, they were more likely due to ontogenetic differences in perceptual motor abilities rather than in learning abilities. Indeed, recent reports of successful learning by 7-day-old rats in a discriminated Y maze for nonnutritive suckling (Kenny \& Blass, 1977), by 3-day-old mice in a shock-escape task (Nagy, Misanin, Newman, Olsen, \& Hinderliter, 1972), and by 1-day-old rats of discriminated barpressing for a milk reward (Johanson \& Hall, 1979) lend support to this conclusion.

This research was supported by Grant HD-09145 from the National Institute of Child Health and Human Development to the first author. Kenneth J. Porada is now at the Department of Psychology, Heidelberg College, Tiffin, Ohio. Requests for reprints should be sent to $Z$. Michael Nagy, Department of Psychology, Bowling Green State University, Bowling Green, Ohio 43403.
On the somewhat more complex active avoidance task, age-related differences in learning ability appear to vary with task difficulty. For example, in a two-way active avoidance task, which requires both excitatory and inhibitory components, 15 - and 17-day-old rats show little evidence of acquisition, whereas learning ability markedly improves between 21 and 51 days of age (Bauer, 1978). On the simplest form of avoidance, a nondirectional one-way active avoidance, rats as young as 10 days of age appear able to acquire the response (Misanin, Chubb, Quinn, \& Schweikert, 1974), although the ability to acquire this task has been reported to improve from 7 to 12 days of age (Spear \& Smith, 1978). For the one-way active avoidance task, reports of age-related learning differences have been mixed. Whereas many of the earlier findings suggested that there were minimal differences between young rats and adults in rates of acquisition (e.g., Feigley \& Spear, 1970; Kirby, 1963; Klein \& Spear, 1969; McLaughlin, Eller, \& Korol, 1975; Riccio \& Marrazo, 1972), others found the young to learn more poorly than adults (e.g., Egger \& Livesey, 1972; Myslivecek \& Hassmannova, 1973, 1979; Riccio et al., 1968). At least part of this discrepancy appears to be due to the criterion of training used in these studies. When the criterion was relatively low, there appeared to be equivalent learning among young and old; when the acquisition criterion has been more stringent, young animals acquired the task more slowly than adults (Potash \& Ferguson, 1977).

The purpose of the present study was to determine the age at which mice first become capable of acquiring and showing 24-h memory for a directional one-way active avoidance task over a fixed number of training trials. Unfortunately, most of the research described in the previous sections was designed to examine memory differences as a function of age rather than of acquisi- 
tion. The two reports that have attempted to trace the development of learning ability for a one-way active avoidance task (Goldman \& Tobach, 1967; Gittis, Note 1) both suffer from the lack of an appropriate control group, specifically, one that receives yoked shock during the initial training sessions. As previous research (Nagy et al., 1972) has shown that prior exposure to shock alone can affect later running speeds in a shock-escape task, the inclusion of a yoked-shock group would seem necessary for the active avoidance task, in which increased speeds could lead to enhanced avoidance behavior during a retention test.

\section{METHOD}

\section{Subjects}

The subjects were 240 Swiss-Webster albino mice (Mus musculus) born and reared in $30.4 \times 18 \times 12.8 \mathrm{~cm}$ polyethylene cages with wire-grid tops and wood chips on the floors. Separate groups of 10 males and 10 females received one-way active avoidance training at $11,13,15,17,19$, and 21 days of age; the same number of like-sex littermates received yoked shock at those ages. Pups from each litter were assigned to age groups according to a modified split-litter design, with each litter represented at two ages. The mothers remained with the pups at all times except during the test sessions; food and water were available ad lib. Temperature was maintained at $24^{\circ} \mathrm{C}$ $\pm 1^{\circ} \mathrm{C}$ in both the colony and test rooms, and all testing was carried out during the light phase of a 12-h light/dark schedule.

\section{Apparatus}

The apparatus consisted of a Plexiglas straight alley, $32.6 \mathrm{x}$ $3.8 \times 6.2 \mathrm{~cm}$, with a grid floor composed of $1-\mathrm{mm}$ stainless steel rods spaced $3 \mathrm{~mm}$ center-to-center running parallel to the length of the alley. The alley was covered with a Plexiglas ceiling, and a removable door formed a 7.2-cm-long startbox. A small Plexiglas platform, $4.8 \times 3.8 \times 1.4 \mathrm{~cm}$, was placed at the goal end of the alley. A $60-\mathrm{Hz}$ scrambled ac shock source (Harvard Instrument Company, Model 3121) delivered .2-mA constant current to the grid floor.

\section{Procedure}

At the appropriate age, each mouse pup receiving active avoidance training was removed from its home cage and placed into the startbox, facing the goal end of the alley. After $5 \mathrm{sec}$, the door was removed, a running-time meter started, and the pup was allowed $10 \mathrm{sec}$ in which to reach and climb up on the platform at the goal end of the alley. If the pup failed to reach the platform within $10 \mathrm{sec}$, shock was initiated and remained on until the pup successfully escaped by climbing up on the platform. Although a maximum latency of $180 \mathrm{sec}$ for an escape was established, mice of all ages escaped the shock within this period. Following either a successful avoidance or an escape response, the pup was allowed to remain on the platform for $5 \mathrm{sec}$ and was then removed and held in the experimenter's closed hand for a 45 -sec intertrial interval. Each pup received 25 such training trials and was then returned to the home cage.

Mice assigned to the yoked-shock group were like-sex littermates of those mice receiving one-way active avoidance training and received treatment immediately after the training session for its littermate. With the exception that the Plexiglas platform was now removed from the goal area, each pup in the yoked-shock group received the identical amounts of handling and shock on each trial as did its trained littermate. Whether or not the yoked mice received shock on any trial depended upon whether its trained littermate had successfully climbed up on the platform within the 10 -sec period and thus avoided the shock on that trial. In this manner, each yoked mouse received virtually identical experience as its trained littermate on each trial, with the impor- tant exception that shock onset or offset was independent of the yoked subject's responses.

Twenty-four hours following training or yoked-shock exposure, each mouse received 25 one-way active avoidance training trials. During the retention tests, each pup had to reach and climb up on the goalbox platform within $10 \mathrm{sec}$ in order to avoid shock onset on each trial.

\section{RESULTS}

Although both the number of successful avoidances and the latencies to climb up on the platform were recorded in this experiment, only the avoidance measure will be reported, as the latency measure proved to be virtually identical in terms of the interpretation of the relationships among the variables of age, training group, gender, and training trials.

\section{Original Training}

The mean numbers of successful avoidances are shown in Figure 1 as a function of age and trial blocks. Active avoidances varied as a function of both age and training trials, with mice 17 days of age and older demonstrating increasing numbers of successful avoidances with continued training, while younger mice exhibited either a decrease or little change in the numbers of avoidances over the training session. A threeway analysis of variance was conducted on these data, with the factors being age, gender, and blocks of five trials. Overall, the number of avoidances was found to increase directly with advancing age $[F(5,108)=14.06$, $\mathrm{p}<.0005]$ and with additional training trials $[\mathrm{F}(4,432)$ $=12.60, \mathrm{p}<.0005]$. Gender was not significant as a main effect $[F(1,108)=.47]$, nor did it interact with any other factor.

The differences among age groups over the training session were evidenced by a reliable Age by Trial blocks interaction $[F(20,432)=7.91, p<.0005]$. Individual

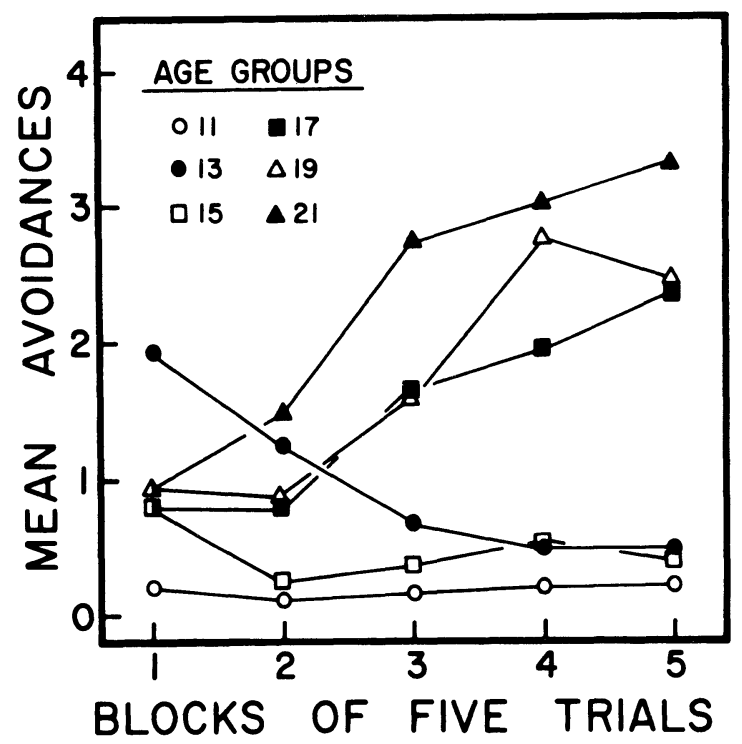

Figure 1. Mean numbers of active avoidance responses during original training as a function of age and blocks of five training trials. 
comparisons conducted within this interaction indicated nonsignificant differences among the age groups during the first trial block, with the exception of the 13-day-old group, which made more successful avoidances than all other ages $[\mathrm{Fs}(1,432)>5.61$, ps $<.025]$. Comparisons made between the first and fifth trial blocks at each age revealed significant increases in shock avoidances for groups 17 days of age and older $[\operatorname{Fs}(1,432)>22.20$, ps $<.0005]$, a reliable decrease for 13-day-olds $[\mathrm{F}(1,432=19.43, \mathrm{p}<.0005] ;$ the 11 - and 15 -day-olds showed little change.

\section{Retention Testing}

The mean numbers of successful avoidances made $24 \mathrm{~h}$ following either avoidance training or yokedshock exposure are shown in Figure 2 as a function of age at initial experience, group, and blocks of five trials. A four-way analysis of variance indicated that successful avoidances increased with age $[F(5,216)=$ $37.21, \mathrm{p}<.0005]$ and over trial blocks $[\mathrm{F}(4,864)=$ $42.18, \mathrm{p}<.0005]$. Individual comparisons conducted within the Age by Trial block interaction $[F(20,864)=$ $7.17, \mathrm{p}<.0005$ ] showed that all groups 18 days of age and older during retest had increasing numbers of avoidances over trial blocks $[\mathrm{Fs}(1,864)>15.62$, ps $<.0005]$. All groups 16 days of age and younger failed to show significant changes $[\operatorname{Fs}(1,864)<2.50]$.

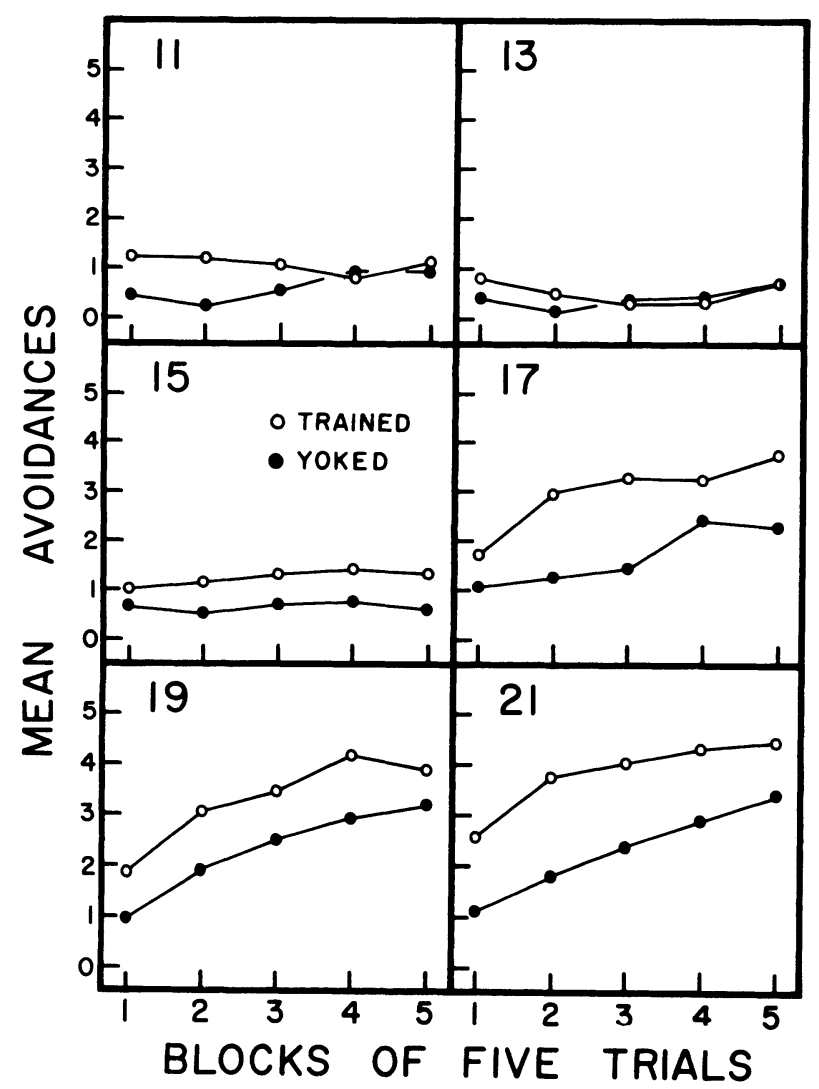

Figure 2. Mean numbers of active avoidance responses made $24 \mathrm{~h}$ following either avoidance training or yoked-shock exposure as a function of age at initial experience, training groups, and blocks of five retention trials.

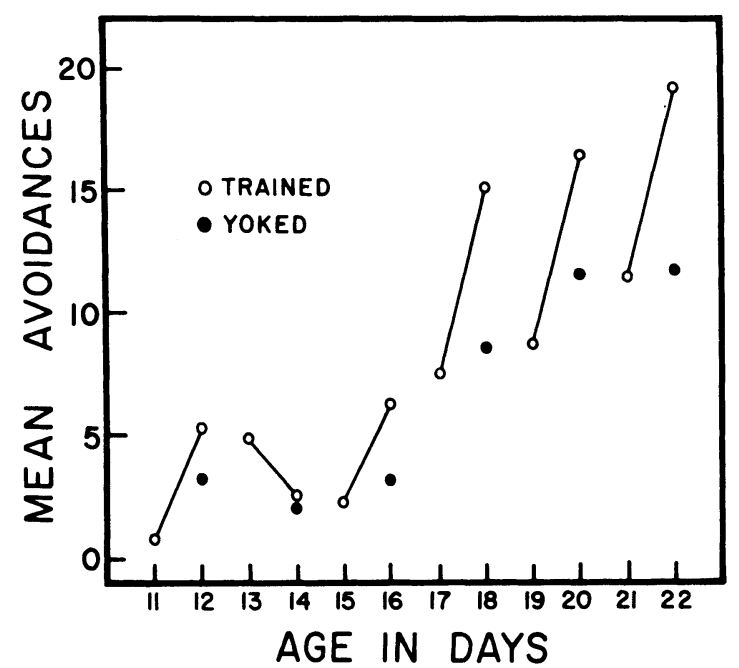

Figure 3. Mean total numbers of active avoidance responses made over the 25-trial training and retest sessions as a function of age and training group.

Overall, mice with prior training made reliably more successful avoidances than did their formerly yoked littermates during the retention tests $[\mathrm{F}(1,216)=29.09$, $\mathrm{p}<.0005]$. Although the Age by Group interaction only approached statistical significance $[\mathrm{F}(5,216)=1.96$, $\mathrm{p}<.10]$, planned comparisons were conducted at each age between the trained and previously yoked groups. These comparisons indicated that previously trained mice made more avoidances than yoked mice when original training occurred at 17,19 , and 21 days of age $[\mathrm{Fs}(1,216)>6.40$, ps $<.025]$, and slightly more when training occurred at 15 days of age $[\mathrm{F}(1,216)=2.87$, $\mathrm{p}<.10]$. Mice trained at 11 and 13 days of age failed to differ reliably from their formerly yoked littermates $[\mathrm{Fs}(1,216)<1.41]$.

To more clearly depict the relationship between age and active avoidance performance, Figure 3 presents the mean total of active avoidance responses made over the 25-trial training and retention sessions as a function of age and group. It is clear from this figure that active avoidance performance shows a marked improvement between 15 and 20 days of age, with only slight further improvement through 22 days of age. We interpret this increase as reflecting the increasing ability of the mice to anticipate the pending shock onset and to successfully avoid it by reaching the platform within the 10 -sec period. From 11 to 15 days of age, however, avoidances appear as an inverted U-shaped function of age. Rather than reflecting differences in learning ability at these ages, we believe these changes to indicate age-related differences in spontaneous activity. In a previous study (Nagy, Murphy, \& Ray, 1975), we have reported spontaneous activity in a similar apparatus to form an inverted U-shaped function, with peak activity occurring at 13 days of age. Whether this early peak level of activity reflects differential maturation of excitatory and inhibitory neurotransmitter systems (Campbell, Lytle, \& Fibiger, 1969; Nagy et al., 1975) or a response to isolation-induced fear (Campbell \& Raskin, 1978; 
Randall \& Campbell, 1976) is unclear at this time. However, it is quite likely that this age-related change in spontaneous activity results in the higher number of active avoidance responses made by 13-day-old mice as compared with 11- and 15-day-old mice in the present study. While these inadvertent avoidance responses might assist the young mouse in learning an active avoidance task, the fact that the 13-day-old group in the present study showed a significant decrease in avoidances over trial blocks would suggest that they do not.

\section{DISCUSSION}

In general, the results of the present study suggest that the ability to learn a directional one-way active avoidance response and to remember it for a 24 -h period develops between 15 and 17 days of age in the Swiss-Webster mouse. Whether these data reflect the emergence of a learning and memory ability per se for this type of learning paradigm rather than one that is specific to the particular parameters of our task is presently not known. For example, it may well be that alteration of the training procedure, such as the addition of an overt CS or additional training trials, may lead to acquisition and retention abilities appearing at earlier ages. Other factors, such as the addition of home-cage cues (Smith \& Spear, 1978), providing approach alternatives (Collier \& Mast, 1979), the use of reactivation procedures (Spear \& Smith, 1978), remain to be investigated to determine the generality of our findings.

Although the conclusion that the ability to acquire oneway active avoidance develops at 17 days of age is as yet tentative, these findings are consistent with the hypothesis that learning abilities vary directly as a function of maturation and task complexity (Nagy \& Sandmann, 1973). Previous research from our laboratory has indicated that, although mice as young as 3 days of age are able to improve their escape performance over a training session (Nagy et al., 1972), they do not appear capable of discriminated escape learning in a T maze until 9 days of age (Nagy \& Murphy, 1974). If one considers the active avoidance task, in which it is necessary to respond before the onset of an aversive stimulus, to be more complex than an escape task requiring responding following the onset of an aversive stimulus, then the later appearance of active avoidance learning would be expected. However, given the fact that there appears to be relatively little difference in locomotor abilities, at least as indexed by spontaneous activity (Nagy et al., 1975), in Swiss mice between 13 and 21 days of age, then some factor other than the ability to make the response (Campbell \& Coulter, 1976 ) is required to account for the age-related learning differences at these ages in the present study.

\section{REFERENCE NOTE}

1. Gittis, A. G. Development of avoidance responses in the neonatal rat. Paper presented at the meetings of the American Psychological Association, Toronto, 1978.

\section{REFERENCES}

BAUER, R. H. Ontogeny of two-way avoidance in male and female rats. Developmental Psychobiology, 1978, 11, 103-116.

Bovet, D., Bovet-Nitti, F., \& Oliverio, A. Genetic aspects of learning and memory in mice. Science, 1969, 163, 139-149.

Campbell, B. A., \& Coulter, X. The ontogenesis of learning and memory. In M. R. Rosenzweig \& E. L. Bennett (Eds.), Neural mechanisms of learning and memory. Cambridge, Mass: M.I.T. Press, 1976.

Campbell, B. A., Lytle, L. D., \& Fibiger, H. C. Ontogeny of adrenergic arousal and cholinergic inhibitory mechanisms in the rat. Science, 1969, 166, 637-638.

Campbell, B. A., Misanin, J. R., White, B. C., \& Lytle, L. D. Species differences in ontogeny of memory: Indirect support for neural maturation as a determinant of forgetting.
Journal of Comparative and Physiological Psychology, 1974, 87, 193-202.

Campbell, B. A., \& RAskin, L. A. Ontogeny of behavioral arousal: The role of environmental stimuli. Journal of Comparative and Physiological Psychology, 1978, 92, 176-184.

Collier, A. C., \& MAst, J. Alleviation of avoidance deficits by approach alternatives in 10-day old rats. Physiology \& Behavior, 1979, 23, 615-618.

Crockett, W. H., \& Nobel, M. E. Age of learning, severity of negative reinforcement, and retention of learned responses. Journal of Genetic Psychology, 1963, 103, 105-112.

Feigley, D. A., \& Spear, N. E. Effect of age and punishment condition on long-term retention by the rat of active- and passive-avoidance learning. Journal of Comparative and Physiological Psychology, 1970, 73, 515-526.

Goldman, P. S., \& Tовасн, E. Behaviour modification in infant rats. Animal Behaviour, 1967, 15, 559-562.

Johanson, I. B., \& HaLL, W. G. Appetitive learning in 1-dayold rat pups. Science, 1979, 205, 419-421.

KENNY, J. T., \& Blass, E. M. Suckling as incentive to instrumental learning in preweanling rats. Science, 1977, 196, 898-899.

KIRBY, R. H. Acquisition, extinction, and retention of an avoidance response in rats as a function of age. Journal of Comparative and Physiological Psychology, 1963, 56, 158-162.

KLEIN, S. B., \& Spear, N. E. Influence of age on short-term retention of active-avoidance learning in rats. Journal of Comparative and Physiological Psychology, 1969, 69, 583-589.

Mclaughlin, L. J., Eller, H. D., \& Korol, B. Acquisition and retention of an avoidance response by rats of different ages. Developmental Psychobiology, 1975, 8, 233-239.

Misanin, J. R., Chubb, L. D., Quinn, S. A., \& Schweikert, G. E. An apparatus and procedure for effective instrumental training of neonatal and infant rats. Bulletin of the Psychonomic Society, 1974, 4, 171-173.

NAGY, Z. M. Development of learning and memory processes in infant mice. In N. E. Spear \& B. A. Campbell (Eds.), Ontogeny of learning and memory. Hillsdale, N.J: Erlbaum, 1979.

Nagy, Z. M., Misanin, J. R., Newman, J. A., Olsen, P. L., \& Hinderliter, C. F. Ontogeny of memory in the neonatal mouse. Journal of Comparative and Physiological Psychology, 1972, 81, 380-393.

NAGY, Z. M., \& MurPhy, J. M. Learning and retention of a discriminated escape response in infant mice. Developmental Psychobiology, 1974, 7, 185-192.

NAGY, Z. M., MurPhy, J. M., \& RAY, D. Development of behavioral arousal and inhibition in the Swiss-Webster mouse. Bulletin of the Psychonomic Society, 1975, 6, 146-148.

NAGY, Z. M., \& Sandmann, M. Development of learning and memory of T-maze training in neonatal mice. Journal of Comparative and Physiological Psychology, 1973, 83, 19-26.

Potash, M., \& Ferguson, H. B. The effect of criterion level on the acquisition and retention of a 1-way avoidance response in young and old rats. Developmental Psychobiology, 1977, 10, 347-354.

RANDAll, P. K., \& CAmpbell, B. A. Ontogeny of behavioral arousal in rats: Effect of maternal and sibling presence. Journal of Comparative and Physiological Psychology, 1976, 90, 453-459.

Riccio, D. C., Rohrbaugh, M., \& Hodges, L. A. Developmental aspects of passive and active avoidance learning in rats. Developmental Psychobiology, 1968, 1, 108-111.

Riccio, D. C., \& Schulenburg, C. J. Age related deficits in acquisition of a passive avoidance response. Canadian Journal of Psychology, 1969, 23, 429-437.

Sмiтh, N. Effects of interpolated learning on the retention of an escape response in rats as a function of age. Journal of Comparative and Physiological Psychology, 1968, 65, 422-426.

Sмith, G. J., \& Spear, N. E. Effects of the home environment on withholding behaviors and conditioning in infant and neonatal rats. Science, 1978, 202, 327-329.

Spear, N. E., \& Smith, G. J. Alleviation of forgetting in preweanling rats. Developmental Psychobiology, 1978, 11, 513-529. 